\title{
A MENTORI ÉS GYAKORNOKI TEVÉKENYSÉG TANULSÁGAI A 2013-AS PILOTPROGRAMOK TÜKRÉBEN: MIT MUTATNAK AZ INDIKÁTOROK?
}

\section{BENCZE RITA}

\author{
az Eszterházy Károly Egyetem Neveléstudományok Doktori Iskola PhD hallgatója \\ bencze.rita@balashazy.unideb.hu
}

Magyarországon a közoktatás-köznevelés elmúlt két évtizede a folyamatos változásról szólt, azonban a legmarkánsabb és legmélyrehatóbb átalakulást a köznevelési törvény elfogadása és benne a pedagógus életpályamodell bevezetése eredményezte, amely a tanárképzés irányát is és hangsúlyait is megváltoztatta.

A pedagógusok szakmai fejlődésének, illetve e fejlődés támogatásának jogszabályi kereteit a 2011. évi CXC. törvény a nemzeti köznevelésről (Nkt), valamint a 326/2013. (VIII. 30.) Kormányrendelet adja. A szabályozás új eleme az életpályamodellként ismert pedagógus-előmeneteli rendszer, a pálya egymásra épülő szakaszolása, melynek bevezető szakasza a gyakornoki státusz.

A gyakornok, hasonlóan más európai és tengerentúli oktatási rendszerek szisztémájához, két évig kezdő pedagógusként dolgozik, és sajátítja el, mélyíti a nevelés és tanítás mesterségének mindazon fortélyait, melyek birtokában valóban kompetens, magasan kvalifikált szakemberré válhat. A mentorok ennek a megújuló iskolai környezetnek fontos szereplői, új feladatokkal gazdagodva.

A gyakornoki rendszer az elmúlt évek során hazánkban is erőteljes hangsúlyt kapott, több kiemelt fejlesztés témája volt, így például az Oktatáskutató és Fejlesztő Intézet TÁMOP-3.1.5/12-2012-0001 Pedagógusképzés támogatása címü projektje, amelynek pilot-kutatása a gyakornok és a mentor szerepelvárásainak megfogalmazását tüzte ki célul.

Emellett párhuzamosan futott az Oktatási Hivatal a gyakornoki minősítővizsgák rendszerének kidolgozását és kipróbálását célzó projektje, amelyben két tanárképző intézmény is részt vett, a Nyugat-magyarországi Egyetem és az Eszterházy Károly Főiskola. A tanulmánykötet az említett két projekt eredményeit ismerteti. ${ }^{1}$

De mi adta a pilotprogramok és az ezt elemző tanulmányok létrejöttéhez az apropót? 2013. szeptember 1-jét (a pedagógus életpálya bevezetését) követően indult két pilotprogram „Gyakornoki Minősitő Vizsgák" és a „Pedagógus jelöltek felkészitése" címmel, az Oktatási Hivatal szervezésében. A program lehetőséget biztosított arra, hogy 150 gyakornokot felkészítsen a próbavizsgára 120 mentor

\footnotetext{
${ }^{1}$ http://www.oktatas.hu/kozneveles/projektek/tamop_315_pedkepzes_fejl/projekhirek/gyak ornoki_pilotprojekt_vegleges Letöltés ideje: 2018.12. 15.
} 
segítségével, akiket a projekt keretében képeztek ki. A programban részt vett még kontrollcsoportként 200 - mentori támogatásban nem részesülő - gyakornok. Ezzel párhuzamosan az Oktatáskutató és Fejlesztő Intézet támogatásával további 20 mentor 50 gyakornokot segített a vizsga elött.

A 2015-ben megjelent, A pedagógusok gyakornoki rendszerének fejlesztése és értékelése címü tanulmánykötet szerzői a két pilotprogram eredményeit foglalják össze. Az egyes tanulmányok elemzései ismertetik a levont konklúziókat, melyek többek között a mentorok által elkészített dokumentumok (,diagnosztikus értékelés","fejlődési terv","mentori munkanapló") elemzésén, a gyakornoki, illetve a mentori attitüd mérése zárt kérdéseket tartalmazó, négyfokozatú Likert-skála típusú önkitöltős kérdőíveken és a kutatók személyes megfigyelői munkáján alapult.

A kötet két nagy egységet ölel fel, az első részben helyet kapott tanulmányok (Falus Iván, Sallai Evva, Ritter Andrea, Fóris Katalin, Hütter Eszter) a gyakornoki kompetenciák diagnosztikus értékelésével, a mentori és gyakornoki tevékenységgel, a gyakornokok által készítendő portfóliókkal és az óvodapedagógiával kapcsolatos, szakmaspecifikus kérdéseket járják körbe. Emellett kiemelt helyet kap a gyakornoki kompetenciák elemzése az indikátorok tükrében, amelyet Falus Iván három önálló tanulmánya foglal egységbe. A kötet második nagy egységében az OFI által vezetett kísérleti program eredményeit ismerhetjük meg. A kötetben megjelenő tanulmányok az alábbi kérdéskörökkel foglalkoznak:

- A diagnosztikus értékelés és egyéni fejlődési terv elemzése

- A mentori tevékenység elemzése

- Óraelemzések

- A gyakornoki személyiségfejlődés elemzése

- A gyakornoki portfólió készítésének tanulságai

- A gyakornoki minősítő vizsga értékelése

- Az indikátorok szerepe a mentori és gyakornoki tevékenységben és az érintettek véleményének összegzése, értékelése

A jól átgondolt és szakmailag professzionálisan kidolgozott kutatást bemutató első rész rendkívül alapos és aprólékos hipotézisrendszert állít fel minden egyes tanulmány elején. Az egyes tanulmányok szerkezetüket tekintve is szerves egységet alkotnak a kötetben, ezzel könnyítve az olvasó számára az egyes tanulmányok közötti összefüggések átlátását: a hipotézisek megfogalmazása, az adatgyüjtés módjának megadása és az eredmények, valamint következtetések levonása révén.

A tanulmánykötet első és második része között azonban erős egyensúlybillenést érezhet az olvasó: a kötet első részének tanulmányai mind tartalmi kidolgozottság, mind terjedelem tekintetében aprólékosabb, szofisztikáltabb válaszokat adnak a felvetett kérdésekre, míg a második rész felvillantja a mentori-gyakornoki tevékenység, mentorálási folyamat egy-egy fontosabb momentumát, az alapvető kérdésekre adott válaszok tömörebbek és kevésbé mélyrehatók, mint az első részben. 
Követve a kötet felépítését, először az első rész tanulmányainak hangsúlyos problémafelvetéseit vesszük számba.

$\mathrm{Az}$ új köznevelési rendszer egyik sarokköve az a nyolcelemú kompetenciarendszer, amelynek már a gyakornokoknak is meg kell ahhoz felelniük, hogy sikeresen teljesítsék a minősítő vizsgát. Ennek értékelésére szolgál az a 77 indikátorból álló rendszer, amely Falus Iván, Fóris Katalin és Hütter Eszter megjegyzése szerint egyaránt érvényes a Pedagógus I. és Pedagógus II. kategóriába való lépéshez (lásd A gyakornoki kompetenciák értékelése - az indikátorok).

A szerzők fontos és elgondolkodtató kérdésfelvetése az is, hogy az indikátorok alapján magasabb pontokat elérő gyakornokok valóban jobban oktatnak-e, mint az adott esetben kevesebb pontot elérő társaik. Ennek megválaszolására a szerzők véleménye alapján még nem áll elegendő adat a rendelkezésünkre.

A mentori tevékenység vizsgálata során az egyik fö szempont az volt, vajon a mentorok mennyire képesek a gyakornokok értékelésekor az egyes kompetenciaelemeket figyelembe venni. Az elemzések azt mutatták, hogy a mentorok hol részletesebben, hol csak egy-két elemet használtak fel a gyakornokok munkájának bemutatásakor, az összes kompetenciaelemet nem vették figyelembe. Ugyanez volt jellemző az indikátorlista esetében is, ez pedig a mentorok felkészítésének hangsúly átrendezését teszi indokolttá, jegyzi meg Falus, A diagnosztikus értékelés és az egyéni fejlödési terv sajátosságai, kapcsolata címü tanulmányában.

A szerző megállapítását támasztják alá az eddig lezajlott minősítési eljárások is, melyek egyértelmüen azt igazolják, hogy áttekinthetetlen a kötelezően elöírt indikátorok száma. A kutatások alapján megfogalmazott észrevétel az indikátorok számának racionalizálása tekintetében azért is megfontolandó, mert semmiképp nem életszerü elvárás akár a gyakornokok, akár a pályakezdő pedagógusokkal szemben, hogy ugyanannyi indikátor alapján lehessen minősíteni őket, mint a már pályán lévő tapasztaltabb pedagógusokat. Hiszen az EU oktatáspolitikája és a magyar életpályamodell által támogatott folyamatos szakmai fejlődés célja éppen az, hogy a pedagógus fejlődése ne csak a pályájára lépést követő egy-két évben tartson, hanem szakmai kontinuumként ölelje fel az egész életutat. Ennek fényében érdemes az indikátorokat átalakítani, illetve hangsúlykülönbségeket megfogalmazni az eltérö életpályaszakaszokban.

Ehhez kapcsolódó, hasonló megállapításra jut Sallai Éva is a mentori tevékenységet elemző tanulmányában (A mentori tevékenységek tapasztalatai): a mentorok szakmai felkészültsége nem kielégítő. Ez a mentorok saját bevallása szerint is tetten érhető például az indikátorokkal való munkában. Az eredmények alapján a szerző kiemeli annak fontosságát, hogy a gyakorlatvezető mentorképzés kötelezővé tételén túl erősíteni kellene a mentorok és Tanárképző Központok közötti együttmüködést, noha a Tanárképző Központok pontos szakmai identitása és szerepe nem egészen egyértelmü. Ezt erősíti az a szerző által közölt adat is, hogy a mentorok 
mintegy 60\%-ának nincs megfelelő mentori képesítése, a 30 órás mentori tréninget végzettek szintén ide sorolandók.

A reflektivitás és reflexióírás fontos elvárásként fogalmazódik meg mind a mentorok, mind a gyakornokok esetében, így a kötetben megjelenő tanulmányok is hangsúlyosan foglalkoznak ezzel a kérdéssel. Ritter Andrea kiemeli A gyakornoki tevékenységek tapasztalatai címü tanulmányában, hogy a reflektivitás fontos eleme az önismeret és énhatékonyság, amelyek segítik az egyén öndefinícóját. A feldolgozott kérdőívek eredményei azonban azt mutatják, hogy a reflexióírás a mentoroknak és a gyakornokoknak egyaránt nehézséget jelentett. Így érthető, hogy a mentorok a reflexivitás fejlesztését önmagukkal szemben is kiemelt fontosságúnak tartották, hiszen ennek hiányában épp az egyik legfontosabb kompetencia fejlesztésében nem tudnak hatékonyan segíteni mentoráltjaiknak.

Ha még mindig e kérdéskörre fókuszálva olvassuk Ritternek a gyakornokok válaszait elemző tanulmányát, azzal a némileg talán meglepő ténnyel szembesülünk, hogy ők sokkal pozitívabban értékelik saját és mentoruk teljesítményét is e tekintetben. A kérdőíves válaszokból az derül ki, hogy a gyakornokok saját önelemző tevékenységük erőteljesebbé válását emelik ki, miközben a mentorral szembeni elvárásukban a reflektivitás erősítése nem jelenik meg ilyen hangsúlyosan. A szerző szerint ez arra enged következtetni, hogy a gyakornokok nincsenek teljesen tisztában a reflexió müfajával.

Falushoz hasonlóan Ritter is megfogalmazza a tanulmány végén, hogy a pedagógusképzőknek kiemelt szerepe kell, hogy legyen a megfelelő kompetenciák fejlesztésében, illetve a reflexióírás mellett a másik kiemelten hangsúlyos és legalább annyi nehézséget okozó feladat a portfólió elkészítése.

Orgoványi-Gajdos Judit tanulmányában (A gyakornokok portfólió készitésének tapasztalatai) a gyakornokok válaszai alapján megállapítja, hogy a portfólió elkészítése idő- és energiaigényes: a mentorok igyekeznek maximális segítséget nyújtani e téren, azonban ezt még mindig kevésnek érzik. A mentorok válaszaiból az derül ki (akik a válaszadók egyharmadát adják), hogy egy egyszerüsített portfóliót szerencsésebbnek tartanának a gyakornokok esetében, illetve kevesebb reflexióra lenne szükség, mert helyenként ez a müfaj, mint pl. IKT eszközök használata, nem releváns. Ezzel egybehangzó megállapítást tesz Falus is a gyakornoki évet elemző tanulmányában (A gyakornoki év egészének és egyes komponenseinek megitélése), illetve mindkét szerző hasonló eredményre jutott abban a tekintetben, hogy a gyakornokok inkább az értékelést, mintsem a személyiségfejlődésüket elősegítő eszköznek tartják inkább a portfóliót. Ez tökéletesen érthető, ha ismerjük a portfólió minősítési rendszerben betöltött szerepét.

Kissné Zsámboki Réka és Katona György az Óvodapedagógia szakterület tapasztalatai címü tanulmányukban a szakterület specifikumait vizsgálták elsősorban, ehhez 5-5 óvodapedagógus mentor és gyakornok anyagát használták fel; majd a vizsgát követően 30 mentor, 30 kísérleti gyakornok és 30 kontrollcsoportos gyakornok töltött ki kérdőívet, az óvodapedagógiára vonatkoztatva. Mind a reflexiót, 
mind a portfóliót tekintve hasonló eredményeket kaptak a korábban említett tanulmányok szerzőihez, ezeket javaslat formájában is megfogalmaznak. Szükségesnek tartanák a reflektív gondolkodást elősegítő kurzusok beépítését az óvodapedagógusok képzésébe, egyszerüsített portfólió feltöltését a gyakornokok esetében, illetve ök is megfogalmazzák, hogy egy rövidebb, egyszerüsített indikátorlista bevezetése is hasznos volna.

Összességében elmondható, hogy szinte minden tanulmányíró megfogalmazta a tanárképző és -továbbképző intézmények kulcsszerepét, a képzések tartalmának finomítását, az új elvárás rendszerhez való igazítását és a megfelelő tartalmakkal való bővítését.

Falus a portfólió kapcsán arra is felhívja a figyelmet, hogy a gyakorlati képzések egyes szakaszait jobban össze kellene hangolni, elkerülve az ismétlődéseket (A gyakornoki év egészének és egyes komponenseinek megitélése), ezzel egyúttal eleget téve az EU-s oktatáspolitika irányelveinek is, amely az Európa Bizottság 2010-ben kiadott Kézikönyvében ennek a veszélynek az elkerülésére hívja fel az érintettek figyelmét. Más szavakkal: ahol az indukciós program bizonyos kompetenciafejlesztési elemeket is tartalmaz, különösen ügyelni kell arra, hogy ne duplikálódjanak a kezdő tanárok számára azon tanulási tevékenységek, amelyeken már részt vettek az egyetemi képzésük során. ${ }^{2}$

A kötet tanulmányait elolvasva átfogó képet kapunk az átalakuló tanárképzés új hangsúlyairól, a benne résztvevők újfajta szerepeiről (gyakornoki státusz, mentor) és a pályaszocializáció nehézségeiről, amelyek mindenkire több és eddig ismeretlen terheket ró. Mivel az indukciós szakasz sikere nagymértékben múlik a mentorok munkáján, így kiemelten fontos, hogy munkájukat hogyan lehet segíteni, hatékonyabbá tenni. Erre több tanulmányban is találunk ajánlásokat. Ugyanakkor megfogalmazódik az idő hiánya, a mentorok órakedvezményének szükségessége, a megfelelö és folyamatos továbbképzés, az órák megbeszélése.

A kötet második részében Az Oktatáskutató és Fejlesztő Intézet TÁMOP3.1.5/12-2012-0001 „Pedagógusképzés támogatása” projekt keretében a gyakornokok minősítő vizsgára való felkészülésének tanulságait összefoglaló tanulmányokat olvashatunk.

Simon Gabriella tanulmánya (A mentorálás szerepe a gyakornokok folyamatos szakmai fejlödésének támogatásában) többek között foglalkozik a mentori szerep jelentőségével a gyakornokok szakmai felkészítése során. A szerző kiemeli annak jelentőségét, hogy a mentorok kiemelt szerepet játszanak a gyakornokok pályaidentitásának alakításában, erősítésében. Talán további adatok gyűjtésével hasznos információkat kaphattunk volna arra a kérdésre, hogy a mentorok a

2 Developing coherent and system-wide induction programmes for beginning teachers: a handbook for policymakers. European Commission Staff Working Document SEC (2010) 538 final 
pályaidentitás erősítése révén a gyakornokok pályán való tartására is hatással tudnak-e lenni. A tanulmánykötet első részének egyik fő gondolatszálát továbbfüzve, szintén érdekes lett volna néhány adatot arról látni, hogy az egyéves program viszonylatában hogyan változott a gyakornokok reflektív naplóinak minősége. S ugyancsak az első részhez kapcsolódva mindenképpen izgalmas kérdés lett volna, hogyan értékelték a mentorok a gyakornokaik input/output kompetenciáinak alakulását az egy év során.

Az egyes kompetenciák bemeneti és kimeneti jellemzőit részletesen mutatja be a kötet legutolsó tanulmánya (Gál Gyöngyi: A gyakornokok fejlödése az adatok tükrében), azonban az adatok értelmezhetőségét nehezíti, hogy a tanulmány gazdagon ellátott grafikonjai folyamatgörbén mutatják be a kompetenciaterületek bemeneti, kimeneti és vizsgaeredményeit, ehelyett az oszlopdiagram szemléletesebben tudta helyesen értelmezni és bemutatni az összefüggéseket.

Mindent egybevetve, a tanulmánykötet két nagy egysége egymást kiegészítő keresztmetszetét adja jelen tanárképzésünk legfőbb és talán legneuralgikusabb pontjainak, amely az átalakulás kataklizmája után kiforrott entitást alkotva, az európai és nemzetközi trendekhez igazodva tudja felkészíteni a jövő fiatal pedagógusait a pályára. E tekintetben rendkívül hasznos alapolvasmánynak tekinthető a kötet minden, a tanárképzésben szereplő szakember számára: egyetemi oktatók, gyakorló iskolai tanárok, mentortanárok egyaránt gazdagodnak a szakmailag igényesen megírt tanulmányokból.

\section{Irodalom}

Developing coherent and system-wide induction programmes for beginning teachers: a handbook for policymakers. European Commission Staff Working Document SEC (2010) 538 final

http://www.oktatas.hu/kozneveles/projektek/tamop_315_pedkepzes_fejl/projekhirek/gyako rnoki_pilotprojekt_vegleges Letöltés ideje: 2018.12.15.

Sallai Éva (szerk. 2015): A pedagógusok gyakornoki rendszerének fejlesztése és értékelése. Oktatási Hivatal, Budapest. 495 oldal 